\title{
SIPA1 Gene Polymorphisms And The Risk Of Breast Carcinoma Among The Egyptian Females: A Pilot Study
}

\section{Amal MH Mackawy ${ }^{1^{*}}$ and Ola Megahed ${ }^{2}$}

${ }^{1}$ Department of Medical Laboratories, Applied Medical Science College, Qassim University, KSA

${ }^{2}$ Department of Pathology, Zagazig University, Egypt

*Corresponding author: Amal M.H. Mackawy, Department of Medical Laboratories, Applied Medical Science College, Qassim University, KSA, Tel: +00966508129407; E-mail: amalmackawy@hotmail.com

Received date: August 19, 2017; Accepted date: December 29, 2017; Published date: January 03, 2018

Copyright: (c) 2018 Mackawy AMH, et al. This is an open-access article distributed under the terms of the Creative Commons Attribution License, which permits unrestricted use, distribution, and reproduction in any medium, provided the original author and source are credited.

\begin{abstract}
Background: Multiple genes are known to influence the cancer metastasis but the effect of the germline heritable genetic polymorphisms on the predisposition and metastasis is not yet well known. Signal-induced proliferation associated gene1 (SIPA1) was considered as a modifying factor in the breast carcinoma (BC) metastasis process. Molecular studies on Sipa 1 gene suggested its essential role as cell adhesion regulator and metastasis modulator. The present study relied on the hypothesis that Sipa1 gene may be contributed to the risk of breast cancer occurrence and aggressiveness as well.
\end{abstract}

Objective: We aimed to examine the association of SIPA1 single nucleotide polymorphisms (SNPs) and human breast cancer incidence and prognosis in Egyptian female patients.

Patient and Methods: Two common SNPs (rs3741378 C>T and rs746429 A>G) were genotyped in 80 Egyptian females; 50 patients with breast cancer and 30 breast carcinoma free females.

Results: The rs3741378 TT genotype enhanced the incidence of breast carcinoma in comparison with the genotypes rs3741378 CC and TC (X2=7.08, $\mathrm{P}=0.029)$, Sipa $1 \mathrm{rs} 3741378 \mathrm{~T}$ allele had a high frequency in $\mathrm{BC}$ cases compared to controls (OR $(95 \%)=2.593(1.339-5.02), P=0.04)$. Sipa 1 rs3741378 TT genotype also displayed significant association with clinical stages, grades and lymph node metastasis $\left(X^{2}=12.73, P=0.013\right),\left(X^{2}=10.88\right.$, $\mathrm{P}=0.028),\left(\mathrm{X}^{2}=6.534, \mathrm{P}=0.010\right.$; OR $\left.(95 \%)=0.324[0.134-0.781]\right)$, respectively. Pointing to those patients carrying the rs3741378 TT genotype had a higher tumor progression rate with advanced tumor grades. Oppositely, these associations could not be detected for $r 5746429 \mathrm{~A}>\mathrm{G}$.

Conclusion: Our results suggest that the Sipa1 promoter rs3741378 C>T SNP was contributed to BC risk and progression, which may be considered as a foretelling biomarker of $\mathrm{BC}$ risk and progression.

Keywords Signal-induced Proliferation Associated Gene1; SIPA 1 polymorphisms; Breast carcinoma; Breast cancer risk factors; Genetics of breast cancer; Breast cancer metastasis.

\section{Introduction}

Breast cancer $(\mathrm{BC})$ is considered as a prime factor of morbidity and low survival rate among other types of cancers in females. In spite of the huge progress in oncology diagnostic maneuvers with progressive treatment regimens, BC still needs extra control to govern its metastasis and improve survival [1]. Till now we are in bad need to enrich our knowledge about BC genetics, which will provide us with new clues for more understanding the individualized disease prognosis and cancer treatment. Multiple upcoming experimental and scientific researches are being accomplished to identify if there is a heritable genetic factors which can influence the therapeutic results of $\mathrm{BC}$ [2]. The progression and metastasis of $\mathrm{BC}$ is so vital in determining the patient chance of recovery and survival rate, so it is very crucial to discover if the germ line polymorphisms can have a role in the tumor progression.
Multiple gene polymorphisms have been identified to be linked with enhanced risk for breast cancer [3,4]. Single nucleotide polymorphism (SNP) of the signal-induced proliferation-associated gene 1 (Sipa1) functional domain was accused of being the supreme gene for the locus Mtes1 which is responsible for tumor progression and dissemination [5]. Sipal is considered to be a mitogen instigator for GTPaseactivating protein which having a regulatory role in the cellular adhesion process [6]. It has been detected that A739T SNP alters the alanine amino acid to threonine in the protein-protein interaction PDZ moiety [7]. Multiple efficacious research data pointed that the mutant Thr allele was characterized by decreased active, GTP-bound Rap1 levels which referred to the looser interaction of the 739Thr Sipa1 protein with its inhibitor, AQP2, causing less inhibitory effect on the Sipal activity.

There are multiple research studies have tried to clarify the metastatic process of breast cancer originating from tumor somatic cell. However, germline polymorphisms contribution to breast cancer metastasis among Egyptian females is not yet well known. Moreover, the influential researches on the cellular level focusing on the SNP 
influence examined the cellular status with different Sipal protein levels, and not with cells carrying the variant genotypes of Sipalgene.

Our objective of this study was to analyze how SIPA1 rs3741378 (Ex3-135 C>T), and rs746429 (-3092 A>G) polymorphisms contribute to $\mathrm{BC}$ predisposition and aggressiveness among the Egyptian female patients.

\section{Patients and Methods}

A total 80 females were contributed in the present study, they were selected from the Database of Pathology Department, Faculty of Medicine, Zagazig University. The research protocol and data handling procedures were ratified by the Zagazig University committee of scientific ethics.

Fifty tumor blocks were archived from female Egyptian patients with breast cancer after modified radical mastectomy or lumpectomy, at the Department of Pathology at the Medical College Zagazig University between May 2014 and October 2016. 34 cases of them with lymph node metastasis and 16 cases without axillary lymph node (LN) metastasis. The diagnosis was pathologically confirmed and reviewed by a pathologist.

Formalin-fixed paraffin-embedded biopsy breast tissue blocks in the Pathology department and their congruent hematoxylin and eosin (H\&E)-stained sections were investigated reviewed by pathologist.

The 50 cancer cases comprised 15 cases were histological grades 1 , 13 cases were histological grades 2, and 22 cases were histological grades 3. According to the American Joint Committee on Cancer TNM classification system we determined the tumor stage with tumor-nodemetastasis (TNM): 10, 11, and 29 cases were in stage I, II, and III/IV, respectively. Tumor grade was assessed conforming to the modified Bloom and Richardson system [8].

Thirty randomly selected control specimens were examined in this study. They had undergone partial mastectomy for benign conditions and all had exclusion criteria from breast carcinoma. The paraffin embedded tissue sections with hematoxylin and eosin staining tissue blocks were examined to confirm the diagnosis and to guarantee the absence of the tumor before DNA isolation. DNA extraction was performed to examine the SIPA1rs3741378 and rs746429 polymorphisms with breast cancer susceptibility and prognosis.

\section{Extraction of DNA}

Dissection was performed to the tissue and prepared for DNA extraction after deparaffinization. Paraffin-embedded tissues were brought down with a surgical blade into $1 \mathrm{~mm}$ pieces, between 25 and $75 \mathrm{mg}$ of each paraffin embedded tissue block was transmitted to a microtube. Genomic DNA was then extirpation from the deparaffinized tissue using the traditional phenol/chloroform method following the proteinase $\mathrm{K}$ digestion [8]. In this experiment, we added similar magnitude of tris-saturated phenol of $\mathrm{pH}=8$ to the tubes and then after centrifugation at 12000 for $3 \mathrm{~min}, 300 \mu \mathrm{l}$ was shuffled to an equal volume of phenol -chloroform mixture (1:1). For the DNA precipitation, centrifugation was done and 2.5 volume of ethanol was added to promote the DNA pellet formation. Gentle washing of the DNA pellet with $70 \%$ ethanol and then the pellet was dried and dissolved in $70 \mu \mathrm{l}$ distilled water to be ready for PCR examination.

\section{SIPA1 Single Nucleotide Polymorphisms Genotyping}

The polymorphisms in SIPA1 (rs3741378 (Ex3-135 C>T) and rs746429 (-3092 A>G) genes were analyzed with PCR-RFLP assay [9]. PCR reaction volume was $25 \mu \mathrm{l}$ containing $1 \times$ Taq standard buffer, 150 pM of each primer, $2.0 \mathrm{mM} \mathrm{MgCl} 2,200 \mu \mathrm{M}$ of each dNTP, $1 \mathrm{U}$ of Taq DNA polymerase (Hoffman-LaRoche, Branchburg, NJ) and template DNA. The sequences of primers for SIPA1.

35 PCR cycles with annealing temperature of $64^{\circ} \mathrm{C}$ for $2760 \mathrm{G}>\mathrm{A}$ polymorphism, while the annealing at $66^{\circ} \mathrm{C}$ and $62^{\circ} \mathrm{C}$ was determined to be the optimal for SIPA1 $545 \mathrm{C}>\mathrm{T}$ polymorphism. Amplification was performed using a thermal cycler (a Perkin Elmer 4800 thermal cycler (PTC-100 machine, MJ Research, Inc., Watertown, Mass. The USA). Following PCR, the amplicons underwent cleavage with different restriction endonucleases.

$545 \mathrm{C}>\mathrm{T}$ polymorphism was detected by BseGI restriction endonuclease (Hoffman-LaRoche). The $\mathrm{C}$ allele resulted in 81 and 47 bp fragments, while T allele uncut. Ssi I enzyme (Hoffman-LaRoche) was used to determine the SIPA1 2760G $>$ A polymorphism, which cut $\mathrm{G}$ allele into 85 and $26 \mathrm{bp}$ fragments (allele A resulted in $111 \mathrm{bp}$ fragment). All PCR-RFLP products were separated via electrophoresis technique (Pharmacia Biotech by SEMKO AB, Sweden) using submarine chamber (Maxiell, EC 360 M-E-C apparatus Cooperation ST. Petersburg. Florida USA) using 3\% agarose gel containing ethidium bromide to be imaged under UV illuminator with 100 base-Pair ladder for fragment length detection.

\section{Statistical Analysis}

To detect the association of the SipA polymorphisms frequencies between the patients and controls. The chi-square test was implemented to compare the frequency of the gene allele and genotype. Moreover, to estimate the gene alleles risk with the breast carcinoma occurrence and progression with different associated risk factors we calculated the odds ratios (ORs) and 95\% confidence intervals (CIs). $P$ value of $5 \%$ was considered significant.

\section{Results}

The study included 80 subjects, 30 controls of mean age \pm SD was $56.5 \pm 10.34$ years and 50 breast cancer patients with the mean age \pm S.D of $58.4 \pm 13.54$ years. All the patients were histologically confirmed breast cancer of paraffin-embedded tumor tissue sections. Age was comparable with all controls and patients $(\mathrm{P}>0.05)$.

All BC patients' characteristics are displayed in Table 1. 34(78\%) of BC patients were Lymph node metastases positive $(\mathrm{LN}+\mathrm{ve})$ and about $16(32 \%)$ only of our cases were detected as LN-ve. Histopathological tumor subtypes revealed that the infiltrating duct carcinoma subtype was more commonly observed than papillary carcinoma subtype (76\% and $24 \%$, respectively) among BC patients.

\begin{tabular}{|l|l|l|}
\hline $\begin{array}{l}\text { SIPA1 Polymorphis } \\
\mathbf{m}\end{array}$ & Sequence \\
\hline $\mathbf{5 4 5}$ C>T (rs3741378) & $\begin{array}{l}\text { Forward } \\
\text { primer }\end{array}$ & 5'-CCAGCTCGGACCTGCTGCAT-3' \\
\hline & $\begin{array}{l}\text { Reverse } \\
\text { primer }\end{array}$ & 5'-GATGGACACGGCCGCGTT-3' \\
\hline $\mathbf{2 7 6 0}$ G>A (rs746429) & $\begin{array}{l}\text { Forward } \\
\text { primer }\end{array}$ & 5'-CCTTGTGCCCACAGTCATGTC-3' \\
\hline
\end{tabular}


Page 3 of 8

\begin{tabular}{|l|l|l|}
\hline $\begin{array}{l}\text { Reverse } \\
\text { primer }\end{array}$ & 5'-CGGGACAGCGACTCCAGAATG-3' \\
\hline
\end{tabular}

Table 1: PCR primer sequences for $545 \mathrm{C}>\mathrm{T}$ and $2760 \mathrm{G}>\mathrm{A}$ SIPA1 SNPs.

Regarding to the American Joint Committee on Cancer TNM classification system, TNM staging revealed: 10(20\%), 11(22\%), and $29(58 \%)$ patients were in stage I, II, and III/IV, respectively. The 50 cancer cases comprised 15 cases were histological grades 1,13 cases were histological grades 2 and 22 cases were histological grades 3 . Tumor grade was assessed in accordance to the modified Bloom and Richardson system $[9,10]$.

To study the effect of SIPA1 rs3741378 (Ex3-135 C>T) and rs746429 SNPs on the susceptibility and prognosis of breast cancer, both SNPs were analyzed in both 30 malignant free normal breast tissue samples and 50 histologically confirmed breast Cancer tissue samples using PCR-RFLP analysis. The frequencies of the genotypes and alleles of the two SNPs are listed in Tables 2 and 3.

\begin{tabular}{|c|c|}
\hline Characters & Number and frequency \\
\hline \multirow{2}{*}{ Age (years) } & Mean \pm S.D \\
\hline & $58.4 \pm 13.54$ \\
\hline \multicolumn{2}{|l|}{ Tumor size : } \\
\hline $0.5 \mathrm{~cm} \leq 6 \mathrm{~cm}$ & $15(30 \%)$ \\
\hline $6 \mathrm{~cm}-12 \mathrm{~cm}$ & $35(70 \%)$ \\
\hline Histopathological types: & $\mathrm{N}(\%)$ \\
\hline Infiltrating duct carcinoma & $38(76 \%)$ \\
\hline Papillary carcinoma & $12(24 \%)$ \\
\hline Lymph node metastasis (LN) & $N(\%)$ \\
\hline$L N+v e$ & $34(78 \%)$ \\
\hline LN -ve & $16(32 \%)$ \\
\hline Estrogen receptor $(E R)+v e$ & $19(38 \%)$ \\
\hline Estrogen receptor (ER) -ve & $31(62 \%)$ \\
\hline Breast cancer Stages total $n=50$ & $\mathrm{~N}(\%)$ \\
\hline Stage I & $10(20 \%)$ \\
\hline Stage II & $11(22 \%)$ \\
\hline Stage III/IV & $29(58 \%)$ \\
\hline Breast cancer Grades $=50$ & $N(\%)$ \\
\hline Grade 1 & $15(30 \%)$ \\
\hline Grade 2 & $13(26 \%)$ \\
\hline Grade 3 & $22(44 \%)$ \\
\hline
\end{tabular}

Table 2: The clinicopathological characters of the studied breast cancer patients.

\begin{tabular}{|c|c|c|c|c|c|}
\hline Genotype & $\begin{array}{l}\text { Controls } \\
(\mathrm{N}=30) \\
(37.5 \%)\end{array}$ & $\begin{array}{l}\text { Cases } \\
(\mathrm{N}=50) \\
(62.5 \%)\end{array}$ & Genotype & $\begin{array}{l}\text { Group } \quad I \\
(\mathrm{~N}=30) \\
(37.5 \%)\end{array}$ & $\begin{array}{l}\text { Group } I I \\
(\mathrm{~N}=50)\end{array}$ \\
\hline \multirow{2}{*}{$\begin{array}{l}\text { rs3741378 } \\
(\text { Ex3-135 } \\
C>T)\end{array}$} & & & rs746429 & & \\
\hline & & & $\begin{array}{l}(-3092 \\
A>G)\end{array}$ & & \\
\hline $\mathrm{CC}$ & $10(33 \%)$ & $8(16 \%)$ & GG & $11(36.36 \%)$ & $24(48 \%)$ \\
\hline CT & $15(50 \%)$ & $20(40 \%)$ & GA & $13(43.33 \%)$ & $17(34 \%)$ \\
\hline TT & $5(16 \%)$ & $22(44 \%)$ & AA & $6(20 \%)$ & $9(18 \%)$ \\
\hline $\mathrm{X} 2$ & \multicolumn{2}{|l|}{7.08} & $\mathrm{x} 2$ & \multicolumn{2}{|l|}{1.03} \\
\hline \multirow[t]{2}{*}{ P-value } & \multicolumn{2}{|l|}{0.029} & P-value & \multicolumn{2}{|l|}{0.599} \\
\hline & $N(\%)$ & $\mathrm{N}(\%)$ & & $\mathrm{N}(\%)$ & $\mathrm{N}(\%)$ \\
\hline C allele & $35(58.33 \%)$ & $36(36 \%)$ & G allele & $35(58.33 \%)$ & $45(45 \%)$ \\
\hline T allele & $25(41.66 \%)$ & $64(46 \%)$ & A allele & $24(40 \%)$ & $35(35 \%)$ \\
\hline $\begin{array}{l}X^{2} \\
P \\
\text { OR } 95 \% \mathrm{Cl}\end{array}$ & \multicolumn{2}{|c|}{\begin{tabular}{|l}
8.147 \\
0.04 \\
$2.593(1.339-5.02)$
\end{tabular}} & $\begin{array}{l}X^{2} \\
P \\
\text { OR } 95 \% C l\end{array}$ & \multicolumn{2}{|c|}{$\begin{array}{l}0.131 \\
0.77 \\
1.34(0.574-2.243)\end{array}$} \\
\hline
\end{tabular}

Table 3: SIPA1 SNPs genotypes distribution between patients and controls.

Regarding the rs3741378 (Ex3-135 C>T) SNP, TT genotypes and T allele frequency were significantly increased in BC patients than in controls $\left(\chi^{2}=7.08, \mathrm{P}=0.029\right)$, odds ratio $(\mathrm{OR})$ of $\mathrm{T}$ allele $\left(\mathrm{X}^{2}=8.147\right.$, $\mathrm{P}=0.04, \mathrm{OR}=2.593,95 \% \mathrm{CI}=1.339-5.02)$.

However, the rs746429 SNP revealed a non- significant difference between the patients and the controls group $\left(\chi^{2}=1.03, \mathrm{P}=0.599\right)$. SNPs with tumor stages results are listed in Table 4. SIPA1 rs3741378 C>T and homozygous TT patients were more likely to have progressive stages (III/IV) $\left(\chi^{2}=12.73, \mathrm{P}=0.013\right), \mathrm{T}$ allele distribution was more increased in BC patients of stage III/IV more than stage I $\left(\chi^{2}=10.971\right.$, $\mathrm{P}=0.001, \mathrm{OR}=0.171,95 \% \mathrm{CI}(0.057-0.514)$. Results regarding the SIPA1 rs746429 SNP genotypes did not significantly differ among different tumor stages $\left(\chi^{2}=4.133, \mathrm{P}=0.127\right)$, however, the A allele carriers of SIPA1 rs746429 SNP were more significantly increased in stage III/IV than stage I $\left(\chi^{2}=5.35, \mathrm{P}=0.026, \mathrm{OR}=0.243,95 \% \mathrm{CI}(0.07-0.843)\right.$.

Moreover, stratifying the patients by tumor grade (Table 5), our results revealed that women carrying the rs3741378 TT genotype and the $\mathrm{T}$ allele carriers had a 4.446 times more increased risk to have grade 3 (grade 3 ) tumor compared to women carrying the CC genotype $\left(\chi^{2}=8.866, \mathrm{P}=0.003, \mathrm{OR}=4.44695 \% \mathrm{CI}(1.62-12.198)\right.$. But results for breast tumor grades and SIPA1 rs746429 SNP did not significantly differ by this study results $\left(\chi^{2}=4.133, \mathrm{P}=0.127\right)$.

SNPs and lymph node metastasis are illustrated in Table 6. Lymph node positive tumors were markedly associated with rs3741378 SNP TT genotype carriers $(\mathrm{OR}=0.289,95 \% \mathrm{CI}=0.120-0.697)$, this significant relationship was not observed between SIPA 1 rs746429 genotypes and lymph node metastases $\left[\chi^{2}=4.941, \quad \mathrm{P}=0.085, \quad \mathrm{OR}\right.$ and $95 \%$ $\mathrm{CI}=0.823(0.358-1.889)]$ (Table 5).

Moreover, in our study an association between rs3741378 C > T SNP (TT genotype and T allele) and ER status was detected $(\mathrm{X} 2=10.03$, $\mathrm{P}=0.007)$. T allele frequency of rs3741378 C $>\mathrm{T}$ SNP had 3.871 (95\% CI 1.631-9.185; $\mathrm{p}=\mathrm{P}=0.002$ ) times higher probability of negative $\mathrm{ER}$ in 
Citation: Mackawy AHM, Megahed O (2018) SIPA1 Gene Polymorphisms And The Risk Of Breast Carcinoma Among The Egyptian Females: A

Page 4 of 8

comparison to those with C allele frequency (Table 6). On the contrary, it was non-significant when analyzed with SIPA1 rs746429 G>A SNP $\left(\chi^{2}=0.214, \mathrm{P}=0.899\right)$ (Table 6).

Chi-Square analysis of our results revealed non -significant frequency difference between the $\mathrm{BC}$ tumor subtypes and the SIPA1 rs3741378 or $\operatorname{rs} 746429$ SNP $\left(\chi^{2}=3.545, \mathrm{P}=0.170\right.$ and $\chi^{2}=0.819$, $\mathrm{P}=0.664$ ), respectively

Our current results reported the association of the SipA1 gene rs3741378 SNP T allele and TT genotype with multiple indicators of the disease process aggressiveness.

\begin{tabular}{|c|c|c|c|c|c|c|c|}
\hline Genotype & $\begin{array}{l}\text { Stage I }(N=10) \\
(20 \%)\end{array}$ & $\begin{array}{l}\text { Stage } \\
(22 \%)\end{array} \quad$ II $\quad(N=11)$ & $\begin{array}{l}\text { Stage III/IV (N=29) } \\
(58 \%)\end{array}$ & Genotype & $\begin{array}{l}\text { Stage I }(\mathrm{N}=10) \\
(20 \%)\end{array}$ & $\begin{array}{l}\text { Stage II }(\mathrm{N}=11) \\
(22 \%)\end{array}$ & $\begin{array}{l}\text { Stage III (N=29) } \\
(58 \%)\end{array}$ \\
\hline 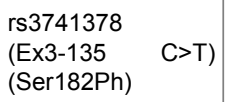 & & & & $\begin{array}{l}\text { rs746429(-3092 } A>G \text { ) } \\
\text { (Ala920Ala) }\end{array}$ & & & \\
\hline $\mathrm{CC}$ & $5(50 \%)$ & $2(18.18 \%)$ & $1(3.4 \%)$ & GG & $4(40 \%)$ & $7(63.63 \%)$ & $13(44.82 \%)$ \\
\hline CT & $3(30 \%)$ & $5(45.45 \%)$ & $12(41.4 \%)$ & GA & $4(40 \%)$ & $2(18.18 \%)$ & $11(37.9 \%)$ \\
\hline TT & $2(20 \%)$ & $4(36.36 \%)$ & $16(55.2 \%)$ & AA & $2(20 \%)$ & $2(18.18 \%)$ & $5(17.24 \%)$ \\
\hline \multirow[t]{2}{*}{$\begin{array}{l}\mathrm{X}^{2}, \mathrm{P} \text {-value among } \\
\text { all tumor stages }\end{array}$} & \multicolumn{3}{|l|}{$12.73,0.013$} & $\begin{array}{l}X^{2}, P \text {-value among all } \\
\text { tumor stages }\end{array}$ & \multicolumn{3}{|l|}{$1.833,0.766$} \\
\hline & Stage I N (\%) & Stage II N(\%) & Stage III N(\%) & & Stage I N(\%) & Stage II N(\%) & Stage III N(\%) \\
\hline $\mathrm{C}$ allele & $13(65 \%)$ & $9(41 \%)$ & $14(24.13 \%)$ & G allele & $12(60 \%)$ & $16(72.7 \%)$ & $37(63.8 \%)$ \\
\hline T allele & $7(35 \%)$ & $13(59 \%)$ & $44(75.86 \%)$ & A allele & $8(40 \%)$ & $6(27.3 \%)$ & $21(36.2 \%)$ \\
\hline $\begin{array}{l}X^{2}, \text { P-value among } \\
\text { all stages }\end{array}$ & \multicolumn{3}{|l|}{$11.07,0.004$} & $\begin{array}{l}\mathrm{X}^{2}, \mathrm{P} \text {-value among all } \\
\text { stages }\end{array}$ & \multicolumn{3}{|l|}{$5.57,0.062$} \\
\hline $\begin{array}{l}\mathrm{X}^{2}, \mathrm{P} \text { value } \\
\text { OR, } 95 \% \mathrm{Cl}\end{array}$ & \multicolumn{3}{|c|}{$\begin{array}{l}X^{2}=2.44, P=0.105^{a} \\
0.373(0.107-1.303)^{a} \\
X^{2}=10.971, P=0.001^{b} \\
0.171(0.057-0.514)^{b} \\
X^{2}=2.86, P=0.082^{c} \\
0.346(0.10-1.20)^{c}\end{array}$} & $\begin{array}{l}X^{2}, P \\
\text { value } \\
\text { OR, } 95 \% \mathrm{Cl}\end{array}$ & \multicolumn{3}{|c|}{$\begin{array}{l}X^{2}=0.764, P=0.293^{a} \\
0.562(0.154-2.057)^{a} \\
X^{2}=5.35, P=0.026^{b} \\
0.243(0.07-0.843)^{b} \\
X^{2}=0.569, P=0.316^{c} \\
1.514(0.514-4.458)^{c}\end{array}$} \\
\hline
\end{tabular}

Table 4: Associations of SIPA1 SNPs genotypes with different breast tumor stages.

\begin{tabular}{|c|c|c|c|c|c|c|c|}
\hline Genotype & $\begin{array}{l}\text { Stage I }(N=10) \\
(20 \%)\end{array}$ & $\begin{array}{lll}\text { Stage } & \text { II } & (\mathrm{N}=11) \\
(22 \%) & & \end{array}$ & $\begin{array}{lll}\text { Stage } & \text { III/IV } & (\mathrm{N}=29) \\
(58 \%) & & \end{array}$ & Genotype & $\begin{array}{l}\text { Stage I }(N=10) \\
(20 \%)\end{array}$ & $\begin{array}{l}\text { Stage } \\
(22 \%)\end{array} \quad$ II $\quad(N=11)$ & $\begin{array}{l}\text { Stage } \\
(58 \%)\end{array} \quad$ III $\quad(N=29)$ \\
\hline $\begin{array}{l}\text { rs3741378 } \\
(\text { Ex3-135 C>T) } \\
\text { (Ser182Phe) }\end{array}$ & & & & $\begin{array}{l}\text { rs746429 } \quad(-3092 \\
A>G)(\text { Ala920Ala }\end{array}$ & & & \\
\hline $\mathrm{CC}$ & $5(50 \%)$ & $2(18.18 \%)$ & $1(3.4 \%)$ & GG & $4(40 \%)$ & $7(63.63 \%)$ & $13(44.82 \%)$ \\
\hline CT & $3(30 \%)$ & $5(45.45 \%)$ & $12(41.4 \%)$ & GA & $4(40 \%)$ & $2(18.18 \%)$ & $11(37.9 \%)$ \\
\hline TT & $2(20 \%)$ & $4(36.36 \%)$ & $16(55.2 \%)$ & AA & $2(20 \%)$ & $2(18.18 \%)$ & $5(17.24 \%)$ \\
\hline $\begin{array}{l}\mathrm{X}^{2}, \quad \mathrm{P} \text {-value } \\
\text { among all tumor } \\
\text { stages }\end{array}$ & \multicolumn{3}{|l|}{$12.73,0.013$} & $\begin{array}{l}\mathrm{X}^{2}, \mathrm{P} \text {-value among } \\
\text { all tumor stages }\end{array}$ & \multicolumn{3}{|l|}{$1.833,0.766$} \\
\hline & Stage I N(\%) & Stage II N(\%) & Stage III N(\%) & & Stage I N(\%) & Stage II N(\%) & Stage III N(\%) \\
\hline C allele & $13(65 \%)$ & $9(41 \%)$ & $14(24.13 \%)$ & G allele & $12(60 \%)$ & $16(72.7 \%)$ & $37(63.8 \%)$ \\
\hline T allele & $7(35 \%)$ & $13(59 \%)$ & $44(75.86 \%)$ & A allele & $8(40 \%)$ & $6(27.3 \%)$ & $21(36.2 \%)$ \\
\hline $\begin{array}{lr}X^{2}, & P \text {-value } \\
\text { among } & \text { all } \\
\text { stages } & \end{array}$ & \multicolumn{3}{|l|}{$11.07,0.004$} & $\begin{array}{l}\mathrm{X}^{2}, \mathrm{P} \text {-value among } \\
\text { all stages }\end{array}$ & \multicolumn{3}{|l|}{$5.57,0.062$} \\
\hline $\begin{array}{l}X^{2} \\
P \\
\text { OR } 95 \% C l\end{array}$ & \multicolumn{3}{|c|}{$\begin{array}{l}X^{2}=2.44, P=0.105^{a} \\
0.373(0.107-1.303)^{a} \\
X^{2}=10.971, P=0.001^{b}\end{array}$} & $\begin{array}{l}X^{2} \\
P \\
\text { OR } 95 \% C l\end{array}$ & \multicolumn{3}{|c|}{$\begin{array}{l}X^{2}=0.764, P=0.293^{a} \\
0.562(0.154-2.057)^{a} \\
X^{2}=5.35, P=0.026^{b}\end{array}$} \\
\hline
\end{tabular}




\begin{tabular}{l|l|l}
$0.171(0.057-0.514)^{b}$ & & $0.243(0.07-0.843)^{b}$ \\
$X^{2}=2.86, P=0.082^{c}$ & & $X^{2}=0.569, P=0.316^{c}$ \\
$0.346(0.10-1.20)^{c}$ & & $1.514(0.514-4.458)^{c}$
\end{tabular}

Table 5: Associations of SIPA1 SNPs genotypes with different breast tumor stages.

\begin{tabular}{|c|c|c|c|c|c|c|c|}
\hline Genotype & $\begin{array}{l}\text { Grade } 1(\mathrm{~N}=15) \\
(30 \%)\end{array}$ & $\begin{array}{l}\text { Grade } 2 \\
(N=13) \\
(26 \%)\end{array}$ & $\begin{array}{l}\text { Grade } 3(N=22) \\
(44 \%)\end{array}$ & Genotype & $\begin{array}{l}\text { Grade } 1(\mathrm{~N}=15) \\
(30 \%)\end{array}$ & $\begin{array}{l}\text { Grade 2 } \\
(\mathrm{N}=13) \\
(26 \%)\end{array}$ & $\begin{array}{l}\text { Grade } 3(\mathrm{~N}=22) \\
(44 \%)\end{array}$ \\
\hline $\begin{array}{l}\text { rs3741378 (Ex3-135 } \\
\text { C>T) (Ser182Phe) }\end{array}$ & & & & $\begin{array}{l}\text { rs746429 } \quad(-3092 \\
A>G) \text { (Ala920Ala }\end{array}$ & & & \\
\hline $\mathrm{CC}$ & $6(40 \%)$ & $1(7.7 \%)$ & $1(4.54 \%)$ & GG & $7(46.7 \%)$ & $5(38.5 \%)$ & $12(54.54 \%)$ \\
\hline СT & $5(3.33 \%)$ & $7(53.4 \%)$ & $8(36.4 \%)$ & GA & $6(40 \%)$ & $6(46.1 \%)$ & $5(22.7 \%)$ \\
\hline TT & $4(26.66 \%)$ & $5(38.5 \%)$ & $13(59.1 \%)$ & $\mathrm{AA}$ & $2(13.3 \%)$ & $2(15.4 \%)$ & $5(22.7 \%)$ \\
\hline$x^{2}$ & \multicolumn{3}{|l|}{10.88} & $x^{2}$ & \multicolumn{3}{|l|}{1.92} \\
\hline \multirow[t]{2}{*}{$P$-value } & \multicolumn{3}{|l|}{0.028} & P-value & \multicolumn{3}{|l|}{0.749} \\
\hline & Grade 1 N\% & Grade $1 \mathrm{~N}(\%)$ & Grade $3 \mathrm{~N}(\%)$ & & Grade $1 \mathrm{~N}(\%)$ & Grade $2 \mathrm{~N}(\%)$ & Grade $3 \mathrm{~N}(\%)$ \\
\hline C allele & $17(56.7 \%)$ & $9(34.6 \%)$ & $10(22.7 \%)$ & G allele & $20(66.7 \%)$ & $16(61.5 \%)$ & $29(66 \%)$ \\
\hline $\mathrm{T}$ allele & $13(43.3 \%)$ & $17(65.4 \%)$ & $34(77.3 \%)$ & A allele & $10(33.3 \%)$ & $10(38.5 \%)$ & $15(34 \%)$ \\
\hline$x^{2}$ & \multicolumn{3}{|l|}{8.94} & $x^{2}$ & \multicolumn{3}{|l|}{4.133} \\
\hline$P$ & \multicolumn{3}{|l|}{0.011} & $P$ & \multicolumn{3}{|l|}{0.127} \\
\hline $\begin{array}{l}X^{2} \\
P \\
\text { OR } 95 \% \mathrm{Cl}\end{array}$ & \multicolumn{3}{|c|}{$\begin{array}{l}X^{2}=2.72, P=0.083^{a} \\
2.47(0.836-7.30)^{a} \\
X^{2}=8.866, P=0.003^{b} \\
4.446(1.62-12.198)^{b} \\
X^{2}=2.36, P=0.107^{c} \\
2.354(0.78-7.102)^{c}\end{array}$} & $\begin{array}{l}X^{2} \\
P \\
\text { OR } 95 \% C l\end{array}$ & \multicolumn{3}{|c|}{$\begin{array}{l}\mathrm{X}^{2}=0.16, P=0.452^{\mathrm{a}} \\
1.25(0.419-3.379)^{\mathrm{a}} \\
\mathrm{X}^{2}=0.48, P=0.332^{\mathrm{b}} \\
0.69(0.242-1.96)^{\mathrm{b}} \\
\mathrm{X}^{2}=0.136, P=0.454^{\mathrm{c}} \\
0.828(0.303-2.264)^{\mathrm{c}}\end{array}$} \\
\hline
\end{tabular}

Table 6: SIPA1 SNPs genotypes distribution with lymph node and estrogen receptor status.

\section{Discussion}

Breast carcinoma is considered as a global health issue among developed countries, to be the uppermost type of tumor among females in the USA and the second cause of death in women [11]. Increase the rate of $\mathrm{BC}$ mortality can be explained by high metastasis and progression complications [12]. The recurrence rate and the relapse of $\mathrm{BC}$ with either positive and negative lymph node metastasis has been determined to reach $50-60 \%$ and $24-30 \%$, respectively [13]. In Egypt, cancer breast represents at $38.8 \%$ among different types of cancers [14].

The incidence of BC in Egyptian young females below 35 years old in Mansoura Province was 8.19\% [15].

SIPA 1 was primarily recognized as a metastatic modulator for breast cancer. Molecular researches on Sipa 1 gene suggested its essential role as cell adhesion regulator and BC metastasis modulator, it modulates cell progression, differentiation, adhesion, and cancer metastasis via activation the Ras-related proteins. Human preliminary epidemiology study displayed that germline SIPA1 gene SNPs are contributed to multiple clinical findings, such as ER and LNM status [16].
SipA1 SNPs contribution to breast cancer incidence and metastasis among Egyptian females is not yet well known. The influence of Sipalgene SNPs on the occurrence of BC, and their associations with clinical properties and progression among Egyptian females have not been examined till now. Moreover, most of the studies were focusing at the influence of the Sipalgene SNPs on Sipal protein levels, and not with the Sipalgene variant genotypes. Our objective was to analyze how SIPA1 rs3741378 (Ex3-135 C>T), and rs746429 (-3092 A>G) polymorphisms contribute to $\mathrm{BC}$ incidence and aggressiveness among the Egyptian female patients via examining the association of sipal SNPs frequency with multiple tumor histological and clinical characteristics, such as tumor stages, grades, tumor subtypes, ER and LNM status.

The current case-control study was conducted to examine the two SIPA1 rs3741378 (Ex3-135 C>T), and rs746429 (-3092 A>G) SNPs, with the occurrence of $\mathrm{BC}$ and prognosis.

Our findings revealed significant increase in TT genotype and T allele of the rs3741378 SNP in BC patients than controls. This finding points to probable protective role of the CC genotype against breast malignancy. Moreover, this finding highlights on the role of that rs3741378 SNP in predisposing the tumorigenesis and malignancy. 
Furthermore, the SIPA1 rs746429 SNP, did not display any correlation with either BC predisposition neither with prognostic factors. However, the A allele carriers of SIPA1 rs746429 SNP were more significantly increased in stage III/IV than stage I $\left(\mathrm{X}^{2}=5.35\right.$, $\mathrm{P}=0.026, \mathrm{OR}=0.243,95 \%$ CI $(0.07-0.843)$. Moreover, SIPA1 rs746429 SNP was also notified to have significant correlations with LNM in other scientific articles.

Our results were in accordance with those of Gaudet et al. [17]. They have explored the same correlation between rs3741378 TT genotype and the risk of breast tumorigenesis.

A study of Hsieh et al. [16] has reported the predisposing effect of SIPA1 rs3741378 to BC. On contrary to our results, they claimed the potential predisposing effect of the CC genotype of SIPA1 rs3741378 (Ex3-135 C>T) to BC, while the TC heterozygous genotype was more frequent in $\mathrm{BC}$ free subjects, that was different from our results.

Hsieh et al. [16] have explained the diversity of the results with the different functional roles of rs3741378 and rs746429 SNPs with progressive $\mathrm{BC}$ stages and grades to be responsible for tumor occurrence and progression, respectively.

We observed significant associations between the rs3741378 (Ex3-135 C>T) SIPA1 SNP and indicators of breast cancer susceptibility and aggressiveness in Egyptian female patients. Mainly, we revealed variable results about some clinical tumor metastasis modulators like the tumor stages, grades, tumor subtypes, lymph nodes metastasis and tumor Estrogen receptor; our results suggested that SIPA1 rs3741378 (Ex3-135 C>T) SIPA1 SNP may influence the susceptibility and the metastatic potential in breast cancer in Egyptian females. However, those findings were not the same with the other rs746429 (-3092 A>G) Sipa 1 SNP.

The current study results reported non-significant correlations of SIPA 1 SNPs with BC occurrence or even with other indicators of tumor aggressiveness.

However, the A allele frequency of rs746429 (-3092 A>G) Sipa 1 SNP was significantly associated with stage III/IV.

SIPA1 influences the expression of the extracellular matrix genes through encoding a GTPase-activating protein [18]. Our findings were similar to Crawford et al. [9], Park et al. [19], Gaudet et al. [17], Packer et al. [20] and Roberts et al. [21] who stated the correlation of SIPA1 rs3741378 with tumorigenesis and survival. However, Crawford et al. [9] and Roberts et al. [21] noticed a correlation of the rs746429 SNP with the increased severity of TNM.

Moreover, Roberts et al. [21] results discovered the correlation of the rs3741378 SNP with the high malignant tumors of HER2- positive and ER/PR-negative.

Regarding to lymph node metastasis, the Sipal rs3741378 T alleles were correlated with lymph node metastasis. Analysis of the Sipa1 rs3741378 CT and TT genotypes, we discovered a correlation with lymph node metastasis. In harmony with our results, Roberts et al reported the link between rs3741378 CT with nodal metastasis.

Nanchari et al. [22] have reported the T allele to be associated with $\mathrm{BC}$ progression. In their study, $\mathrm{T}$ allele was found to be highly represented in advanced disease stages, and it was related to +ve LN and HER2 negative receptor status. Our findings supported the results of Nanchari et al. [22], we determined an association between $\mathrm{T}$ allele and G3 tumor grade, which is related to bad prognosis.
The association of SIPA1 rs3741378 and rs746429 genotype status and tumor size were not examined in our study but previous studies have demonstrated a linear correlation between tumor diameter and the lymph node involvement [23]. SIPA1 SNP may enhance the tumor progression and lymph node affection even with small tumor size. Further analysis of these SNPs is needed to illustrate the correlation.

Our current results stated that SIPA1 rs3741378 but not the rs746429 SNP was also associated with other indicators of tumor aggressiveness. Furthermore, the rs3741378 SNP was correlated with ER-negative tumor in our sample of Egyptian patients. Roberts et al. [21] have claimed similar to our results,

Sex hormone positive receptor is associated with appropriate predictors, such as decreased cellular generation and tumor discernment [24].

Exonic missense of $545 \mathrm{C}>\mathrm{T}$ SNP the Serine amino acid (S) is replaced by Phenylalanine amino acid (F) with hydrophobic moiety causing alteration in the physico-chemical properties and modify SIPA1 action. This can explain the effective correlation with the sex hormone influence on the tumorigenesis and metastasis process.

Hsieh et al. [16] have observed an increase of CT genotypes expression in controls and they have explained that finding with CT genotype cells having changes in the protein affinity and interaction, which may have potential effect on variable oncogenic cascade and alteration in the gene cell cohesion.

Moreover, previous studies on the same $545 \mathrm{C}>\mathrm{T}$ SNP showed its correlation with hormonal receptors (estrogen and progesterone receptor), and they referred the protective roles of a CC genotype to its effects on these pathways. Those findings focus on the mischievous effect of SIPA1 germline SNP has on breast cancer prognosis and denote that different forms of this gene are correlated with the tumor aggressiveness

In harmony to our results, Ugenskienè et al. [25] and Pei et al. [26] have found that TT and CT genotype of $545 \mathrm{C}>\mathrm{T}$ considered as a negative predictor for metastatic free survival in $\mathrm{BC}$ patients. Our results are powered by considering the findings of other multiple different experimental studies together with recognized SIPA1 gene biological actions [27-29].

The ability of the cancerous cells to metastasize is not only resulted from somatic mutation, but also due to hereditary factors which may affect the tumorigenesis in some type of tumors.

These genetic mutations and polymorphisms may dramatically affect the oncogenesis process which can affect the tumor progression and metastasis [9].

Those different experimental studies may assist in disbanding the entanglements of hereditary influences on sporadic human cancer [30].

It is essential to analyze the accurate effects of SIPA1 on the tumor progression and metastasis modification to clarify its correlation to the breast cancer tumorigenesis and progression [9].

Germline SIPA1 polymorphism may modify the cancerous cell response to oncogenesis via modification of cellular architecture and charges which inhibit the intracellular oncogenic process. SIPA 1 regulate Rap 1 negatively which has been involved in the epithelial polarization [31] and intercellular adherent junctions [32]. For more 
explanation and clarification of those multiple results foregoing researches will be essential.

Yi et al. [33] studied the relation between SIPA1 and breast cancer, they have reported a correlation of rs746429 with breast carcinoma. Although, the rs931127 and rs3741378 SNPs did not show any association with breast carcinoma.

Tsukamoto et al. [23] and $\mathrm{Su}$ et al. [34] have explored the importance of Rap1 GTP for cellular interaction through soluble factors and extracellular matrix as the $\beta 1$-integrins, which are negatively regulated by SPA-1. It modify the protein PDZ domain which negatively affect the cytoskeletal-anchoring protein AF6 [34].

Moreover, Ishida et al. [35] and Largaespada et al. [36] have recorded the potent effects of SIPA-1 on cellular proliferation in murine studies which accelerate the environment for tumor metastasis.

All those previous different studies support the results of the present case-control study, in which we found that germline SIPA1 the $545 \mathrm{C}>\mathrm{T}$ polymorphism is associated with increased the predisposition and metastatic efficiency in breast tumor in Egyptian females.

However, further more experiments and researches on larger sample size and with different epidemiological and clinical characters are essential to clarify the exact effect of the SIPA1 gene SNPs on BC tumorigenesis and metastasis in Egypt.

The importance of our study is that being the first to study these SNPs of Sipa-1 gene in Egyptian females and examined the possible effect of those SNP genotypes on the BC predisposition and tumor metastasis from available breast tissues, which is considered to be one of the means to assess the prognosis of breast cancer.

We have to admit that our study had several limitations. Firstly - a small sample size, secondly - lack of data on other SNPs in analyzed genes. Despite these limitations, our results uphold the correlation of SIPA1 and RRP1B SNPs to BC prognosis. Further studies on larger cohorts should be conducted to confirm our findings.

\section{Conclusion}

Our results have denoted the crucial molecular influences of the SipA1 gene rs3741378 T allele and TT genotype on the breast cancer predisposition, metastasis, and aggressiveness.

Although the rs746429 SNP was not correlated to tumor properties, lymph node metastasis and tumorigenesis, except that A allele was significantly associated with tumor stage.

These results indicated that germline SIPA1 SNP is significantly correlated to multiple indicators of the disease process aggressiveness such as tumor progressive stages, tumor grades and other clinical characters, not only as negative indicators but also as predictors for tumorigenesis that could help in the treatment strategy. Ongoing multiple studies are required to clarify more the correlation of the SIPA1 gene with breast tumorigenesis and prognosis.

\section{Acknowledgement}

We are thankful to the Medical Biochemistry Lab, Pathology lab and Zagazig University Hospital for the technical assistance and for the recruitment of control samples and $\mathrm{BC}$ patients tissue samples.

\section{References}

1. Youlden DR, Cramb SM, Yip CH, Baade PD (2014) Incidence and mortality of female breast cancer in the Asia-Pacific region. Cancer Biol. Med 11: 101-115.

2. Choi JY, Nowell SA, Blanco JG, Ambrosone CB (2006) The role of genetic variability in drug metabolism pathways in breast cancer prognosis. Pharmacogenomics 7: 613-624.

3. Easton DF, Pooley KA, Dunning AM, Pharoah PD, Thompson D, et al. (2007) Genome-wide association study identifies novel breast cancer susceptibility loci. Nature 447: 1087-1093.

4. Hunter DJ, Kraft P, Jacobs KB, Cox DG, Yeager M, et al. (2007) A genome-wide association study identifies alleles in FGFR2 associated with risk of sporadic postmenopausal breast cancer. Nat Genet 39: 870-874.

5. Shimizu Y, Hamazaki Y, Hattori M, Doi K, Terada N, et al. (2011) SPA-1 controls the invasion and metastasis of human prostate cancer. Cancer Sci 102: 828-836.

6. Kurachi H (1997) Human SPA-1 gene product selectively expressed in lymphoid tissues is a specific GTPase-activating protein for Rap1 and Rap2. Segregate expression profiles from a rap1GAP gene product. J Biol Chem 272:1-8.

7. Park YG, Clifford R, Buetow KH, Hunter KW (2003) Multiple cross and inbred strain haplotype mapping of complex-trait candidate genes. Genome Res. 13: 118-121.

8. Cawkwell LQ (2002) Direct multiplex multiplication of DNA from formalin fixed, paraffin wax embedded tissue section. J Clin Pathol: Mol Pathol 53: 51-52.

9. Crawford NPS, Ziogas A, Peel DJ, Hess J, Anton-Culver H (2006) Germline polymorphisms in SIPA1 are associated with metastasis and other indicators of poor prognosis in breast cancer. Breast Cancer Res. 8: R16.

10. Bloom HJ, Richardson WW (1957) Histological grading and prognosis in breast cancer; A study of 1409 cases of which 359 have been followed for 15 years. Br J Cancer 11: 359-377.

11. Jemal A, Tiwari RC, Murray T, Ghafoor A, Samuels A, et al. (2004) Cancer statistics 2004; CA Cancer J Clin 54: 8-29.

12. Guarneri V, Conte PF (2004) The curability of breast cancer and the treatment of advanced disease. Eur J Nucl Med Mol Imaging 1: S149-161.

13. Chung CT, Carlson RW (2003) Goals and objectives in the management of metastatic breast cancer. Oncologist 8: 514-520.

14. Ibrahim AS, Khaled HM, Mikhail NNH, Baraka H, Kamel H (2014) Cancer Incidence in Egypt: Results of the National Population-Based Cancer Registry Program. Journal of Cancer Epidemiology 2014: 18.

15. Omar F, Mohamed A, Ahmad S, Ziad E, Waleed A, et al. (2016) Breast cancer characteristics in very young Egyptian women $\leq 35$ years. Breast Cancer (Dove Med Press) 8: 53-58.

16. Hsieh SM, Smith RA, Lintell NA, Hunter KW, Griffiths LR (2009) Polymorphisms of the SIPA1 gene and sporadic breast cancer susceptibility. BMC Cancer 9: 331 .

17. Gaudet MM, Hunter K, Pharoah P, Dunning AM, Driver K, et al. (2009) Genetic variation in SIPA1 in relation to breast cancer risk and survival after breast cancer diagnosis. Int J Cancer 124: 1716-1720.

18. Crawford NPS, Walker RC, Lukes L, Officewala JS, Williams RW, et al. (2008) The Diasporin Pathway: a tumor progression-related transcriptional network that predicts breast cancer survival. Clin Exp Metastas. 25: 357-369.

19. Park YG, Zhao X, Lesueur F, Lowy DR, Lancaster M, et al. (2005) Sipal is a candidate for the metastasis efficiency modifier locus Mtes1. Nat Genet 37: 1055-1062.

20. Gaudet MM, Hunter K, Pharoah P, Dunning AM, Driver K, et al. (2009) Genetic variation in SIPA1 in relation to breast cancer risk and survival after breast cancer diagnosis. Int J Cancer 124: 1716-1720.

21. Roberts MR, Hong C, Edge SB, Yao S, Bshara W, et al. (2013) Case-only analyses of the associations between polymorphisms in the metastasis 
Citation: Mackawy AHM, Megahed O (2018) SIPA1 Gene Polymorphisms And The Risk Of Breast Carcinoma Among The Egyptian Females: A Pilot Study . J Integr Oncol 7: 202. doi:10.4172/2329-6771.1000202

Page 8 of 8

modifying genes BRMS1 and SIPA1 and breast tumor characteristics, lymph node metastasis, and survival. Breast Cancer Res Treat 139: 873-885.

22. Nanchari SR, Cingeetham A, Meka P, Damineni S, Tipirisetti N, et al. (2015) Rrp1B gene polymorphism $(1307 \mathrm{~T}>\mathrm{C})$ in metastatic progression of breast cancer. Tumour Biol. 36: 615-621.

23. Tsukamoto N, Hattori M, Yang H, Bos JL, Minato N (1999) Rap1 GTPase-activating protein SPA-1 negatively regulates cell adhesion. J Biol Chem 274: 18463-18469.

24. Platet N, Cathiard AM, Gleizes M, Garcia M (2004) Estrogens and their receptors in breast cancer progression: a dual role in cancer proliferation and invasion. Crit Rev Oncol Hematol 51: 55-67.

25. Ugenskienè R, Myrzaliyeva $\mathrm{D}$, Jankauskaitė $\mathrm{R}$, Gedminaitė J Jančiauskiene R, et al. (2016) The contribution of SIPA1 and RRP1B germline polymorphisms to breast cancer phenotype, lymph node status and survival in a group of Lithuanian young breast cancer patients. Biomarkers 21: 363-370

26. Pei R, Xu Y, Wei Y, Ouyang T, Li J, et al. (2013) Association of SIPA1 545 $\mathrm{C}>\mathrm{T}$ polymorphism with survival in Chinese women with metastatic breast cancer. Front Med 7: 138-142.

27. Hunter KW, Broman KW, Voyer TL, Lukes L, Cozma D, et al. (2001) Predisposition to efficient mammary tumor metastatic progression is linked to the breast cancer metastasis suppressor gene Brms1. Cancer Res 61: 8866-8872.

28. Rae JM, Skaar TC, Hilsenbeck SG, Oesterreich S (2008) The role of single nucleotide polymorphisms in breast cancer metastasis. Breast Cancer Res 10: 301 .
29. Zhang Y, Gong Y, Hu D, Zhu P, Wang N, et al. (2014) Nuclear SIPA1 activates integrin $\beta 1$ promoter and promotes invasion of breast cancer cells. Oncogene 34: 1451-1462.

30. Ewart-Toland A, Briassouli P, de Koning JP, Mao JH, Yuan J, et al. (2003) Identification of Stk6/STK15 as a candidate low-penetrance tumorsusceptibility gene in mouse and human. Nat Genet 34: 403-412.

31. Ohba Y, Ikuta K, Ogura A, Matsuda J, Mochizuki N, et al. (2001) Requirement for C3G-dependent Rap1 activation for cell adhesion and embryogenesis. EMBO J 20: 3333-3341.

32. Yajnik V, Paulding C, Sordella R, McClatchey AI, Saito M, et al. (2003) DOCK4, a GTPase activator, is disrupted during tumorigenesis. Cell 112: 673-684.

33. Yi SM, Li GY (2013) The association of SIPA1 gene polymorphisms with breast cancer risk: evidence from published studies. Tumour Biol. 35: 441-445.

34. Su L, Hattori M, Moriyama M, Murata N, Harazaki M, et al. (2003) AF-6 controls integrin-mediated cell adhesion by regulating Rap1 activation through the specific recruitment of Rap1GTP and SPA-1. J Biol Chem 278: 15232-15238.

35. Ishida D, Kometani K, Yang H, Kakugawa K, Masuda K, et al. (2003) Myeloproliferative stem cell disorders by deregulated Rap1 activation in SPA-1-deficient mice. Cancer Cell. 4: 55-65.

36. Largaespada DA (2003) A bad rap. Rap1 signaling and oncogenesis. Cancer Cell 4: 3-4. 